\title{
The contribution of airport retail to total airport revenues
}

\author{
Sumayyah Akoodie \\ C. E. Cloete \\ Department of Construction Economics, University of Pretoria \\ Pretoria, South Africa
}

\section{Keywords}

Airport, airport revenues, aeronautical revenues, non- aeronautical revenues, retail, airport retail, retail concessions

\begin{abstract}
Purpose: Airports globally are facing pressure on income from aeronautical fees and are placing increasing importance on non-aeronautical sources of revenue. The largest contributions to non-aeronautical revenues are from retail, parking, and property sources. Airport operators generally aim to increase non-aeronautical revenue to fifty percent of total revenues, to compensate for the risk of a decline aeronautical revenues. This study analyses the change in airport revenues for the past decade and the correlating growth of airport retail income of the Airports Company of South Africa (ACSA), which is the largest airport authority in Africa.

Methodology: An analysis of the financial statements and integrated reports of the Airports Company of South Africa (ACSA), was undertaken for the (financial years 2010/11 to 2018/19.

Findings: The results indicate that although non-aeronautical revenues of ACSA have been increasing during the period of analysis, its contribution to total revenue still lags slightly behind aeronautical revenues. A strong positive correlation was found to exist between other non-aeronautical sources of revenue and airport retail growth.

Practical implications: ACSA can further increase its total revenues by expanding the scope of retail operations at the nine airports under its jurisdiction, to approximate an equal contribution to aeronautical revenues. It is recommended that further research be undertaken to extend the scope of the study by increasing the period of analysis and by including other airport owners and operators in South Africa.
\end{abstract}

Acknowledgement

The second author (Chris Cloete) acknowledges the financial support of the South African Council of Shopping Centres through endowment of the SACSC Chair in Shopping Centre Studies at the University of Pretoria

\section{Introduction}

Airports are generally considered one of the most complex systems in modern society (Kazda and Caves, 2007; Kraal, Popovic and Kirk, 2009). The main objective of an airport is to bring together people, processes, technology, government agencies, private companies, spaces, artefacts and information in order to allow for flights to depart and arrive on schedule (Kazda and Caves, 2007; Kraal et al. 2009). Airports further serve as vital sources of income to both developed countries and developing countries (Tourism Forecasting Committee, 2011). Due to the current financial decline in world economies, it is regarded as important to maintain or improve the income from the airport industry (London First, 2008).

\section{Literature review}

Revenue Sources for Airport Operations

Airport revenues comprise of aeronautical as well as non-aeronautical revenue sources (Graham, 2013). Aeronautical revenue sources include landing fees, charges for air traffic control services, aircraft parking, passenger charges, cargo charges and charges for aircraft handling (Heyes, 2014). Nonaeronautical revenue sources, on the other hand, include rent, utility charges, concessions, airport shops, interest, and real estate (Heyes, 2014).

\section{Changes in Airport Revenues}

From the mid-1990's, airports began to focus on non-aeronautical revenues. (Francis, Humhreys \& Ison, 2004; Bilotkach, Clougherty, Mueller \& Zhang, 2012; Graham, 2009; Fuerst, Gross, \& Klose, 2011). 
Non-aeronautical areas have become a primary source of revenue for airports, as on average, the commercial revenues account for approximately half of all airport revenue (Moodie, 2007; Graham, 2009).

Case studies examining airport revenues

A number of studies of airport revenues and revenue resources had been undertaken (Doganis, 1992; Wells \& Young, 2004; Graham, 2008; Asford et al., 2011; De Neufville et al., 2013; Gillen and Martin, 2014; Francis et al., 2004; Bilotkach, Clougherty, Mueller \& Zhang, 2012; Graham, 2009; Fuerst et al., 2011; Battal \& Bakir, 2017; Zhang \& Zhang, 1997; Niemeier, 2002; Czerny, 2006; Saounatsos, 2007; Freathy \& O'Connell, 1999).

Van Denver (2007) established that non-aeronautical revenues of fifty-five (55) major US airports were more than half of all incomes between 1998 and 2002. This is supported by Appold \& Kasarda (2006), Moodie, (2007) and Graham $(2008,2009)$ who concluded that non-aeronautical revenues have increased to, on average, half of all airport revenues. However, this ratio varies by global region.

Aeronautical revenues and non-aeronautical revenues of five of Europe's busiest airports in terms of number of passengers were analysed by means of vertical percentage analysis and trend analysis method (Battal \& Bakir, 2017). The five airports have significantly increased both aeronautical revenues and non-aeronautical revenues. However, the ratio tended to decrease over the years (Battal \& Bakir, 2017).

Fuerst et al. (2011), in a study of aeronautical revenues and the amount of non-aeronautical revenues per passenger of the leading Europe airports concluded that the aeronautical revenue per passenger was higher in busier airports.

The revenue structure varies per continent and even per country or per airport (Battal \& Bakir, 2017). For instance, the proportion of non-aeronautical revenues accounts for more than half of the total revenues at airports in North America, Africa and the Middle East, 46-48\% in all revenues in the AsiaPacific and about 30\% in Latin America (Battal \& Bakir, 2017). Rimmer (2011) states that non-aeronautical revenue sources account for $47 \%$ of the total airport revenues. Non-aeronautical sources now generate between $35 \%$ and $40 \%$ of the total airport revenues (Kramer, Landau, Letwin \& Moroney, 2015). Oum, Adler and $\mathrm{Yu}$ (2006) further indicate that the share of non-aeronautical revenues are much higher than aeronautical revenues in the private airports.

Among the non-aeronautical revenues composed of many activity items, the most important sources are retail sales, contributing $22 \%$ of the total income, real estate contributing $19 \%$ and car park revenues contributing 18\% (Graham, 2008; Fuerst et al., 2011).

Importance of Non-Aeronautical Revenue Sources

Airports have started to actively develop their share of non-aeronautical revenues (Bohl, 2013). A number of researchers have stressed the increasing importance of non-aeronautical or commercial revenues for airports (Papagiorcopulo, 1994; Freathy \& O'Connel, 2000; Graham, 2003; Francis et al., 2004; Graham, 2008). According to Freathy (2004), the objective for many airport authorities has been to reposition the airport to become a commercial attraction in its own right, instead of merely offering limited assortment, price-based, branded products. This is achieved by segmenting the customer base and providing a focused range of shopping facilities, which then provides a consistent income stream for the retailer and the airport authority (Freathy, 2004). By allocating more space to services and retail, airports are able to generate more income (Bearingsdottir, 2019).

The share of non-aeronautical revenues of total airport revenues is directly proportional to passenger numbers, as shopping, catering, and car-parking facilities are extended with increasing passenger numbers (Bohl, 2013). Industry data suggests that this share typically grows to approximately $40-50 \%$ of total income once airports have reached 8-10 million passengers annually (Bohl, 2013).

With airport revenues having shown a large improvement with commercialisation (Francis et al., 2004), airport managers are required to actively to look for new business models that are designed to capitalise on non-aeronautical revenue sources (Heyes, 2014).

\section{Contributions to Non-Aeronautical Revenue}

Retail concessions remain the largest source of non-aeronautical revenue for airports, contributing $30.2 \%$ to airports non-aeronautical revenue (ACI, 2019). Car parking revenue and property revenue and 
rent are the second and third largest sources of non-aeronautical revenues, comprising $20.1 \%$ and $15.0 \%$, respectively (ACI, 2019).

\section{Growth of Airport Retail}

Since its introduction in the 1940's, both the physical presence and the financial importance of the retail environment within the airport industry have substantially increased (Freathy and O'Connell, 1999; Newman and Lloyd-Jones, 1999; Omar, 2001). The airport retail market is now considered to be a distinct market (Livingstone, 2014). It differs from non-airport retail markets, for example shopping centres, in that it contains a wide variety of both traditional shopping outlets as well as specific airport and travelrelated outlets (Livingstone, 2014).

Formerly airports comprised of limited dining, retail, and convenience options post the security check-in (Crawford and Melewar, 2003). The airport environment is largely driven by unique geographical constraints: it contains "ground-side" and "air-side" environments (Herring, 2002). The addition of increased security measures in recent years further allowed airports to capitalise on the retail opportunities, since passengers were required to arrive at airports earlier (Tymkiw, 2016). This led to longer waiting times at terminal gates, hence increased discretionary periods for passengers and greater opportunities for airport retail (Rowley \& Slack, 1999). Thus, airports began by transforming the retail environment to that of shopping centres. These expanded shopping areas often include a mix of high-end retail shops, spas, hotels, and other amenities (Tymkiw, 2016).

The airport environment now serve as an important space within which passengers are able to utilise their discretionary time (Rowley and Slack, 1999), with retail amongst the activities that passengers can undertake.

\section{Methodology}

Airports Company South Africa SOC Ltd (ACSA) is the largest airport authority in Africa. Founded in 1993, ACSA operates nine of South Africa's airports, including O. R. Tambo International. ACSA has two distinct revenue streams, which have generated similar income for the past few years. One source is defined as aeronautical income and is derived from regulated charges or tariffs. These consist of aircraft landing and parking charges, and passenger service charges. The non-aeronautical income is generated from commercial undertakings and flows from retail operations, car parking, car rental concessions, advertising, property leases and hotel operations.

Data collection involved the collection of the annual financials and integrated reports of ACSA for the ten financial years from $2009 / 10$ to $2018 / 19$.

These annual financials of the company were analysed to compare aeronautical revenue, with nonaeronautical revenue, to establish the possible growth trends of revenues and airport retail.

\section{Results} Operations

Contribution of Non-Aeronautical Sources of Revenue Relative to Aeronautical Sources in Airport

The revenue composition of aeronautical and non-aeronautical revenues for ACSA is depicted in Figure 1. As also illustrated by the trend lines in Figure 2, non-aeronautical revenues contributed more to airport revenue than aeronautical revenues in FY 2009/10. However, since FY 2010/11 aeronautical revenues have contributed more than non-aeronautical revenues to the total airport revenue. The non-aeronautical revenue contribution to total airport revenue witnessed a decline from FY 2010/11 to FY 2012/13, however, the non-aeronautical revenue contribution to total revenue stabilised at 36\%-37\% to FY 2016/17. The strategy by ACSA to enhance non-aeronautical revenue is however evident from FY $2017 / 18$, where non-aeronautical revenue contribution increased significantly and at present slightly lags behinds the aeronautical revenue contribution to total airport revenue by $5 \%-6 \%$. 


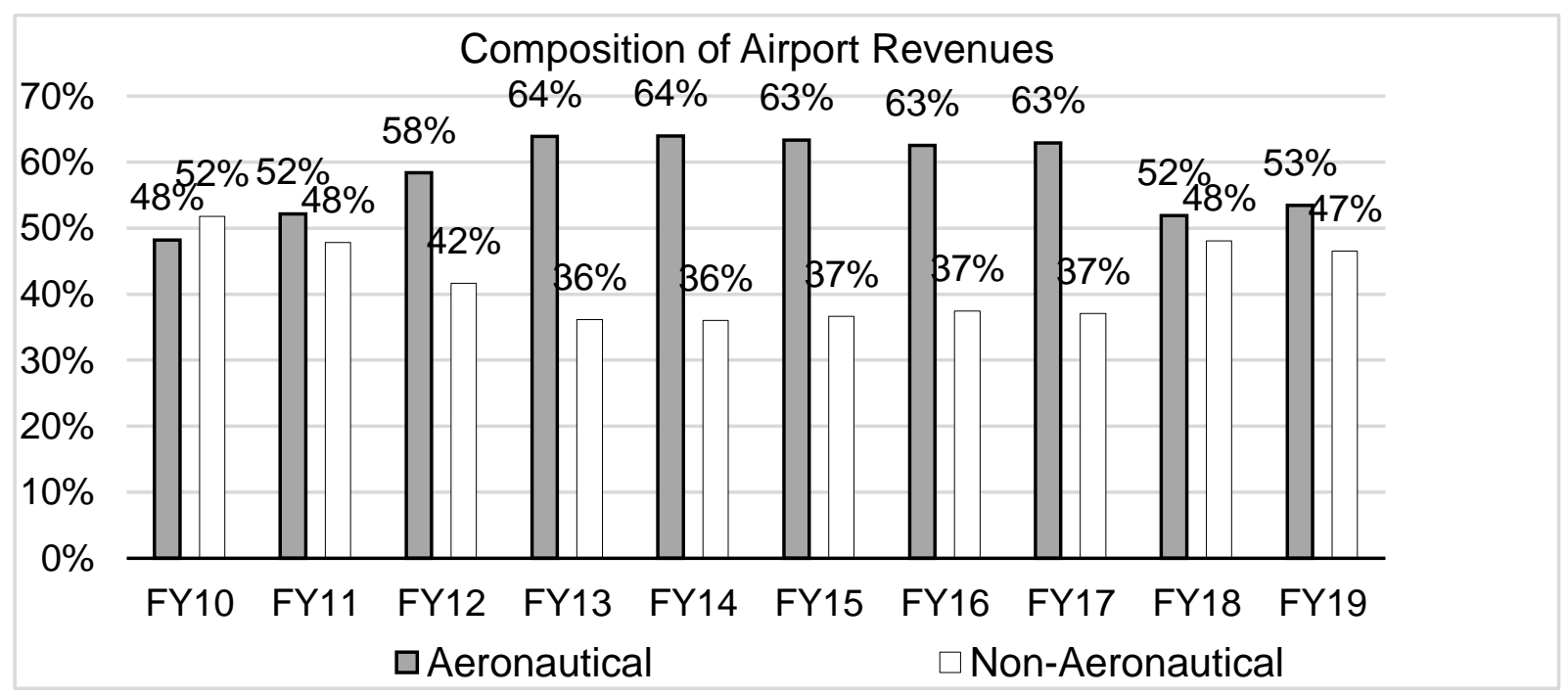

Figure 1: FY 2009/10 to FY 2018/19 Revenue Composition

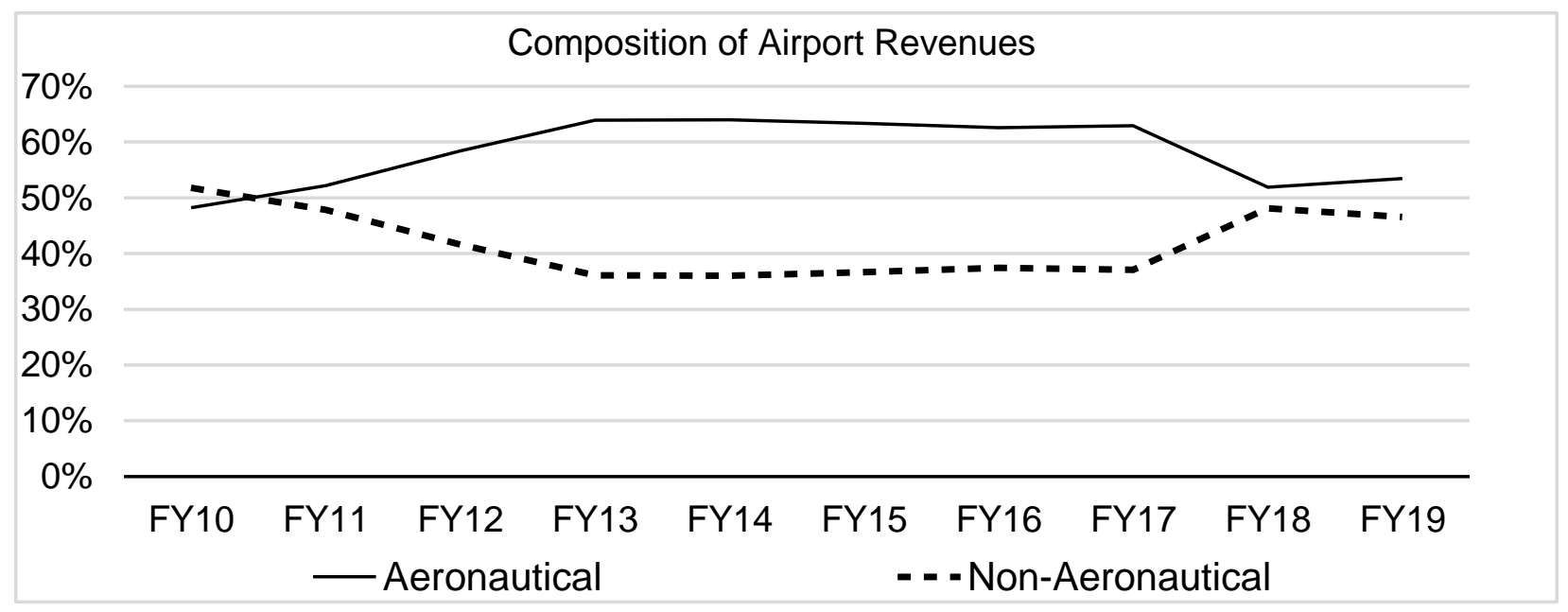

Figure 2: FY 2009/10 to FY 2018/19 Revenue Composition Movement

Growth Trend of Non-Aeronautical Sources of Revenue Relative to Aeronautical Sources in Airport Operations

The year on year growth of non-aeronautical and aeronautical revenues for ACSA are depicted in Figure 3. Non-aeronautical revenue is characterised by a more stable growth line than that of nonaeronautical revenue. The volatility of the latter is largely due to the regulatory constraints which impact on aeronautical revenues, and subsequently aeronautical revenue growth.

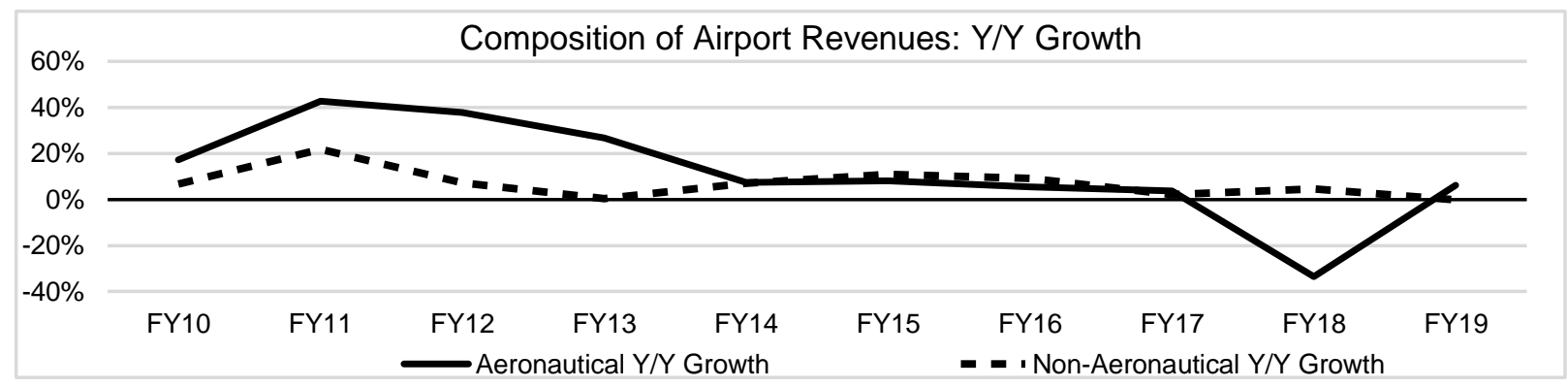

Figure 3: FY 2009/10 - FY 2018/19 Airport Revenues Y/Y Growth 
For the financial year's FY 2009/10 to FY 2016/17, a directly proportional growth between aeronautical and non-aeronautical revenue exists. Exceptions however occur in FY 2013/14, FY 2017/18, and FY 2018/19 where an inversely proportional growth was found.

It must be highlighted that a change in tariffs in 2017/18 resulted in a significant decrease in aeronautical revenues. However, non-aeronautical revenue subsequently witnessed growth due to increase passenger traffic driven by the lower tariffs.

The year-on-year growth variance of aeronautical and non-aeronautical revenues is depicted in Figure 4.

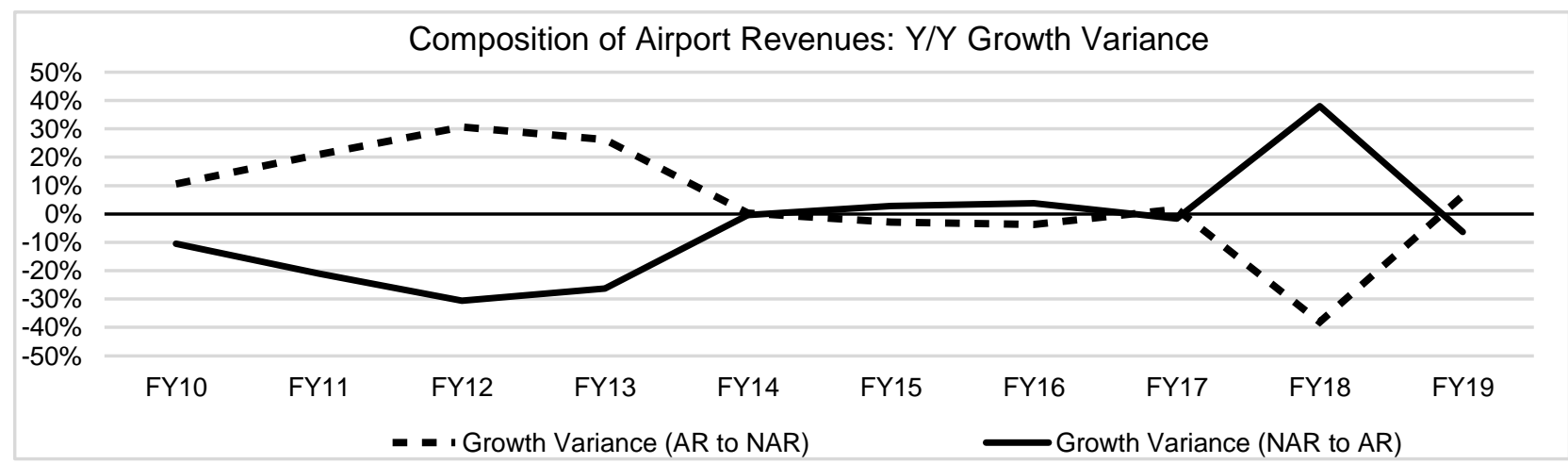

Figure 4: FY 2009/10 - FY 2018/19 Airport Revenues Y/Y Growth Variance

It is evident that the year-on-year growth of aeronautical and non-aeronautical revenues is for the most part directly proportional, however, the extent of the variance year on year varies.

Contribution of Airport Retail or Retail Concessions to Non-Aeronautical Sources of Revenue Sources

The contribution of the airport retail or retail concessions is depicted in Figure 5.

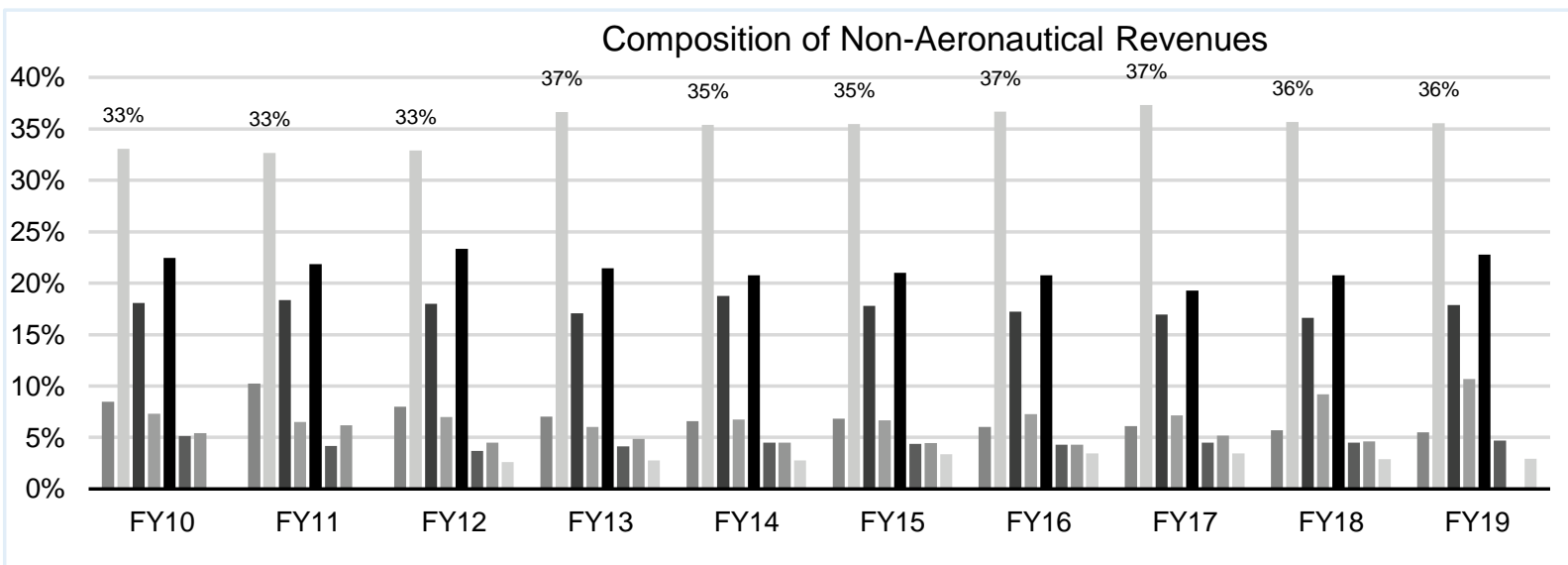

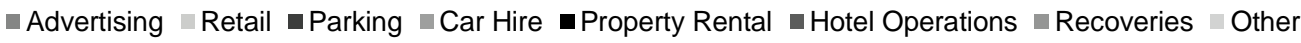

Figure 5: FY 2009/10 - FY 2018/19 Non-Aeronautical Revenue Composition

The retail segment has been the largest contributor to non-aeronautical revenues since FY 2009/10, as detailed in Figure 6 . The minimum contribution in any given year stands at $33 \%$ with the maximum contribution being $37 \%$. 


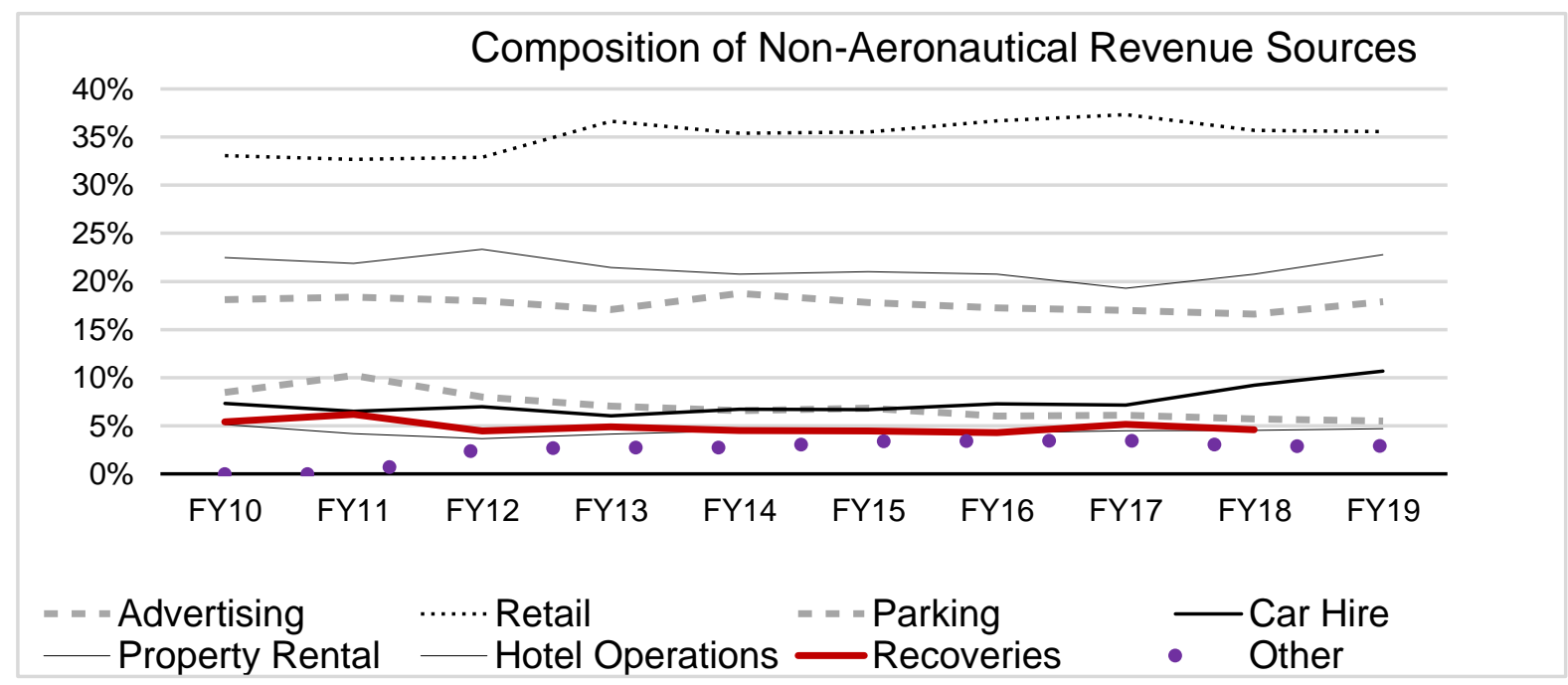

Figure 6: FY 2009/10 to FY 2018/19 Non-Aeronautical Revenue Composition Movement

As also illustrated in Figure 7, the retail contribution to non-aeronautical revenue remained at 33\% for three successive years after which its contribution peaked to 37\% in FY 2012/13. This increased contribution was short lived as the retail contribution decreased to $35 \%$ for two successive years. The retail contribution to non-aeronautical revenue since FY 2015/16 has stabilised to 36\%-37\%.

Growth of Airport Retail in Relation to other Non-Aeronautical Revenue Sources

The year on year growth of airport retail or retail concessions and the remaining sources of nonaeronautical revenue for ACSA is detailed graphically in Figure 8.

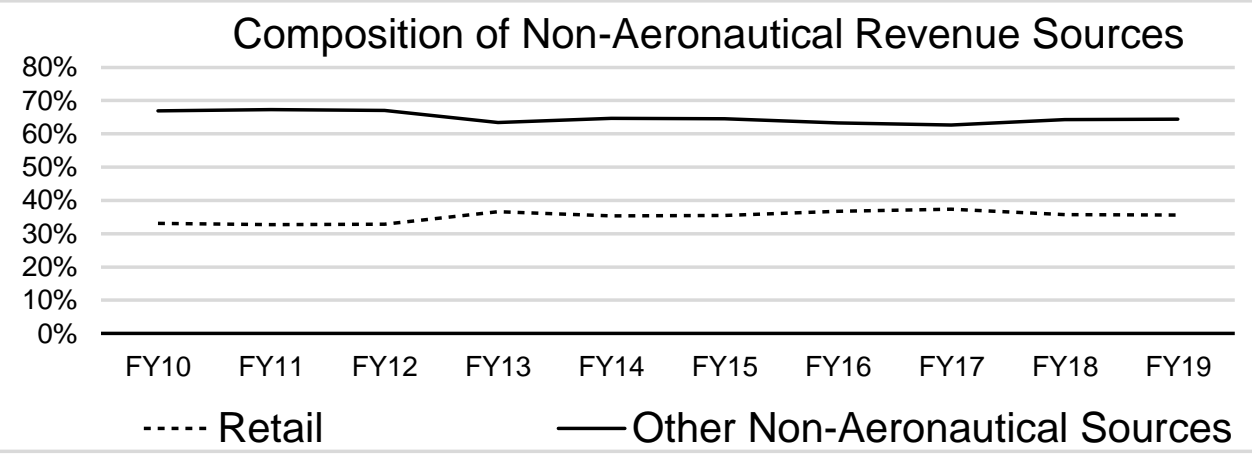

Figure 7: FY 2009/10 to FY 2018/19 Retail and Non-Aeronautical Revenue Composition Movement

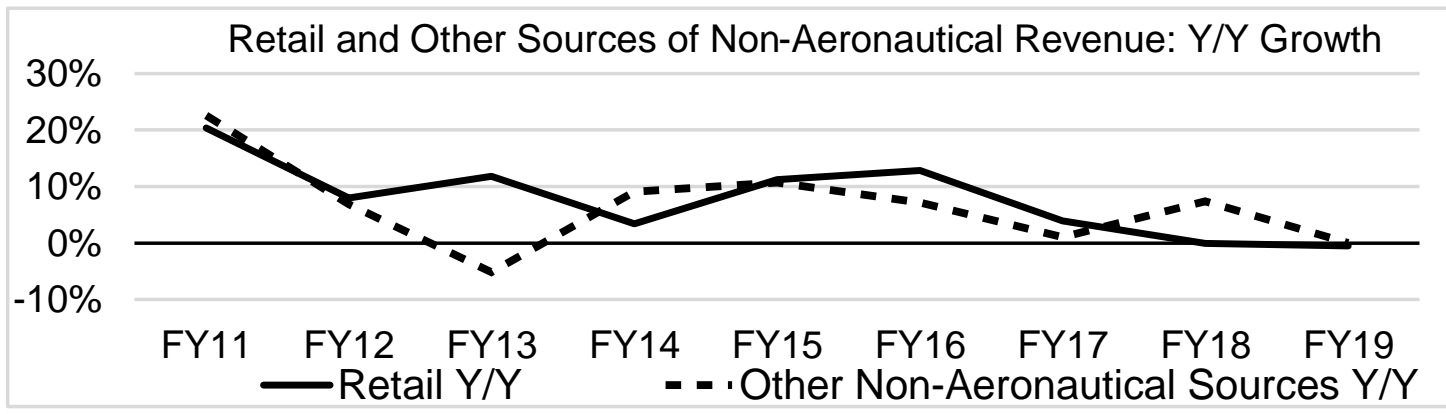

ure 8: FY 2009/10 to FY 2018/19 Retail or Retail Concessions and Other Sources of Non-Aeronautical Revenue Growth 
For financial years FY 2010/11 to FY 2018/19, directly and indirectly proportional growth exists over the various years.

The year on year growth variance of retail concessions and non-aeronautical revenues is detailed accordingly with the extent of the growth variance detailed graphically in Figure 9.

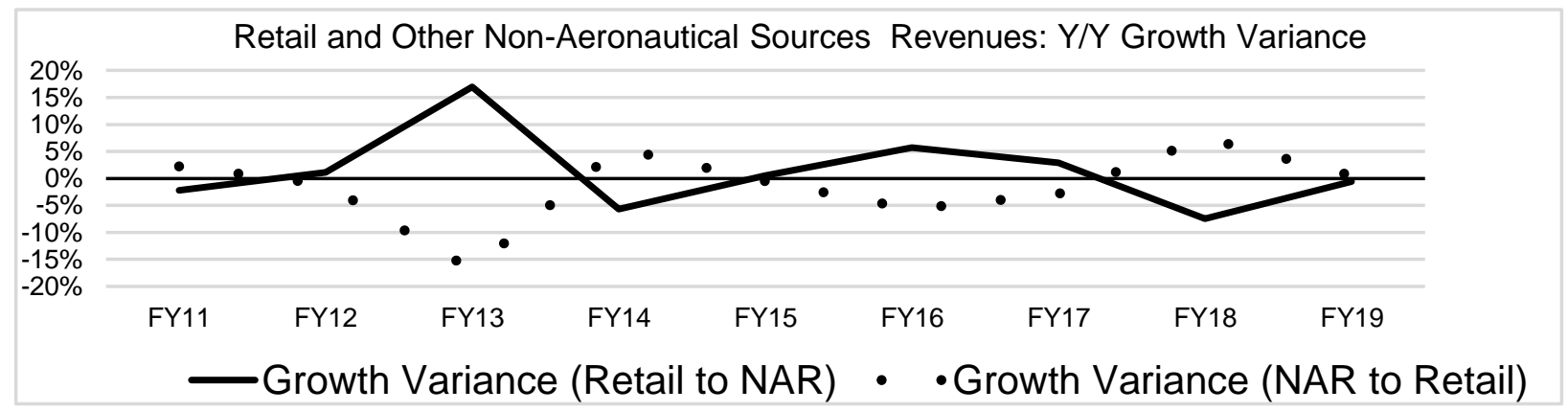

Figure 9: FY 2009/10 - FY 2018/19 Retail and Other Non-Aeronautical Sources Y/Y Growth Variance Correlating Growth of Retail to Aeronautical, Non-Aeronautical and Total Revenues

The correlation between the growth of retail concessions and aeronautical revenue exhibits a co-efficient (R) of 0.7391 , representing a moderate positive correlation.

The correlating growth between retail concessions and other sources aeronautical revenue in terms of Pearson's Correlation exhibits a co-efficient (R) of 0.9707 representing a strong positive correlation.

The correlating growth between retail concessions and other sources of aeronautical and nonaeronautical revenue in terms of Pearson's Correlation exhibits a co-efficient (R) of 0.8392 representing a strong positive correlation.

\section{Discussion}

Aeronautical versus Non-Aeronautical Sources of Revenue

ACSA obtains its revenues from aeronautical and non-aeronautical revenue sources (ACSA, 2019). This is in line with airports operations globally Graham, 2003; Graham, 2008; Graham, 2013; Doganis, 1992; Carlisle, 2015; Freathy \& O'Connel, 2000).

Landing fees, passenger service charges and aircraft parking charges constitute the aeronautical revenue of ACSA (ACSA, 2019). Non-aeronautical revenue sources relate to commercial revenues and include terminal area concessions, car parking areas, airline leased areas and other leased facilities (Doganis, 1992). Retail, advertising, parking, car hire, property rental, hotel operations, recoveries and other (permits and airport management services) constitute the aeronautical revenue of ACSA (ACSA, 2019).

Contribution of Non-Aeronautical Sources of Revenue relative to Aeronautical Sources of Revenues in Airport Operations

The volatility in the airline industry has made it difficult for airport operators to rely exclusively on aeronautical sources of revenue (Everett, 2014), hence non-aeronautical revenues are now becoming a primary source of revenue for airports (Moodie, 2007; Graham, 2009). The revenue structure varies per continents and even per country or per airport (Battal \& Bakir, 2017). The share of non-aeronautical revenues as a proportion of total revenues have increased over the years (Oum, Adler \& Yu, 2006). On average, however, the commercial revenues account for approximately half of all airport revenue (Moodie, 2007; Graham, 2009).

ACSA has increased its non-aeronautical revenue contribution to total revenue from $36 \%-37 \%$ since FY $2012 / 13$ to $47-48 \%$ in the past two financial years. This increase in non-aeronautical revenue contribution is in line with the Group's strategy and the strategies of majority of airports globally (ACSA, 2019).

Growth Trend of Non-Aeronautical Sources of Revenue relative to Aeronautical Sources of Revenues in Airport Operations 
A transition in the airport business model has been evidenced (Kramer, 2010). In the 1970's, airports provided infrastructure services to support services and airlines whilst in the 1980's and largely from the mid-1990's, airports began place to focus on non-aeronautical revenue sources (Kramer, 2010). As airports began to develop a significant amount of non-aeronautical services, they began to gain a large share of revenues from the non-aviation industry (Klos, 2014). The share of non-aeronautical revenues of total airport revenues was directly proportional to passenger numbers, as shopping, catering, and car-parking facilities are expanded with increasing passenger numbers (Bohl, 2013).

ACSA evidenced a predominantly directly proportional relationship between aeronautical revenue and non-aeronautical revenue. As aeronautical revenues achieved growth, non-aeronautical revenues achieved growth and vice versa. The extent of the growth however varied year on year.

Contribution of Airport Retail or Retail Concessions of Revenue relative to Non-Aeronautical Sources of Revenues in Airport Operations

Among the non-aeronautical revenues, the most important sources are retail sales, real estate, and car park revenues (Graham, 2008; Fuerst et al., 2011). Published results by ACI (2019) indicates that retail concessions remain the largest source of non-aeronautical revenue for airports contributing $30.2 \%$ to airports non-aeronautical revenue. Car parking revenue and property revenue and rent are the second and third largest sources of non-aeronautical revenues comprising $20.1 \%$ and $15.0 \%$ of airports nonaeronautical revenues, respectively (ACI, 2019).

ACSA in line with airports globally has seen its retail segment being the largest contributor to nonaeronautical revenues since FY 2009/10, with the contribution ranging between $33 \%$ and $37 \%$. Since FY $2015 / 16$, the retail contribution to non-aeronautical revenue has stabilised to $36 \%-37 \%$. The contribution of airport retail to non-aeronautical revenue is however $6 \%-7 \%$ higher than the average retail contribution of $30 \%$.

\section{Contribution of Airport Retail or Retail Concessions in relation to Non-Aeronautical Sources of Revenues}

The last five years has seen airport retail report an average annual sales growth of $14 \%$ (including duty-free and duty-paid sales) (Little, 2009). This was due mainly by the strategy of airports to develop non-aeronautical revenues. In order to secure a targeted return on investment, airports now aim to achieve $50 \%$ of revenues from non-aeronautical sources, with retail representing the main source. As a result, airports have increased the space dedicated to duty-free shops significantly (Little, 2009). ACSA has experienced a similar growth in airport retail. It has evidenced direct and indirect proportional growth of airport retail in relation to other sources of non-aeronautical sources of revenue during the last 8-10 years.

Correlating growth of Airport Retail or Retail Concessions of Revenue relative to Aeronautical, Non-Aeronautical and Total Revenues

The efforts of airports to develop revenue from non-aeronautical sources have been driven strongly by growth in the airport retail sector. The sector will become more strategic as the decline in air traffic forces airports to reduce their dependency on airline fees (Little, 2009).

The financial statements of ACSA exhibit a positive correlation growth between airport retail revenues and aeronautical revenues, non-aeronautical revenues (excluding retail revenue); and total revenues (excluding retail revenue), respectively

The correlation with aeronautical revenue is moderately positive, with a strong positive correlation with non-aeronautical revenue (excluding retail) and with total revenue (excluding retail).

\section{Future research}

Airport revenue composition has changed over the last few years with increasing focus on nonaeronautical revenues. Retail or retail concessions globally is the largest contributor to non-aeronautical revenues. A strong positive correlation exists between airport retail and other non-aeronautical sources of revenue. It is recommended that future research be extended to include other airports not owned and operated by ACSA; that the temporal boundary of the study be extended to the inception of ACSA to obtain a truly historical analysis of airport revenue composition and growth; and that the study be expanded to determine the per passenger growth of airport retail. 


\section{References}

ACI. (2019). ACI Economics Report affirms the importance of non-aeronautical revenues for airports' financial sustainability. [Online] Available from https://aci.aero/news/2019/03/28/aci-economics-report-affirms-the-importance-ofnon-aeronautical-revenues-for-airports-financial-sustainability/ [Accessed 13/07/2019]

ACSA. (2010). Annual Report 2010. Bedfordview: Airports Company South Africa SOC Limited.

ACSA. (2011). Annual Report 2011. Bedfordview: Airports Company South Africa SOC Limited.

ACSA. (2012). Annual Report 2012. Bedfordview: Airports Company South Africa SOC Limited.

ACSA. (2013). Integrated Report 2013. Bedfordview: Airports Company South Africa SOC Limited.

ACSA. (2014). Integrated Report 2014. Bedfordview: Airports Company South Africa SOC Limited.

ACSA. (2014). Financial Statements 2014. Bedfordview: Airports Company South Africa SOC Limited.

ACSA. (2014). Abridged Audited Financial Statements for the year ended 31 March 2014. Bedfordview: Airports Company South Africa SOC Limited.

ACSA. (2015). Integrated Report 2015. Bedfordview: Airports Company South Africa SOC Limited.

ACSA. (2015). Annual Financial Statements 2015. Bedfordview: Airports Company South Africa SOC Limited.

ACSA. (2016). Integrated Report 2016. Bedfordview: Airports Company South Africa SOC Limited.

ACSA. (2016). Annual Financial Statements 2016. Bedfordview: Airports Company South Africa SOC Limited.

ACSA. (2017). Integrated Report 2017. Bedfordview: Airports Company South Africa SOC Limited.

ACSA. (2017). Annual Financial Statements 2017. Bedfordview: Airports Company South Africa SOC Limited.

ACSA. (2018). Integrated Report 2018. Bedfordview: Airports Company South Africa SOC Limited.

ACSA. (2018). Annual Financial Statements 2018. Bedfordview: Airports Company South Africa SOC Limited.

ACSA. (2019). Integrated Report 2019. Bedfordview: Airports Company South Africa SOC Limited.

ACSA. (2019). Annual Financial Statements 2019. Bedfordview: Airports Company South Africa SOC Limited.

Appold, S. J. \& Kasarda, J. D. (2006). The Appropriate Scale of US Airport retail activities. Journal of Air Transport Management, 12, 277-287.

Asford, N. J., Mumayiz, S. \& Wright, P. H. (2011). Airport Engineering Planning, Design and Development of 21st Century Airports (4th Edition). New York: John Wiley \& Sons.

Battal, U. \& Bakir, M. (2007). The Current Situation and Change in Airport Revenues: Research on The Europe's Five Busiest Airports. International Journal of Academic Research in Business and Social Sciences, 7(7), 287-303

Bearingsdottir, H. B. (2009). Airport Service Quality, Satisfaction and Loyalty Membership -The case of Keflavik and Landvetter Airports. Gothenburg: University of Gothenburg

Bilotkach, V., Clougherty, J. A., Mueller, J., \& Zhang, A. (2012). Regulation, Privatization and Airport Charges: Panel Data Evidence from European Airports. Journal of Regulatory Economics, 42(1), 73-94.

Bohl, P. (2013). The Impact of Airport Retail Environment on Passenger Emotions and Behaviour. Budapest: Corvinus University of Budapest.

Carlisle, A. (2015). Airport business resilience: Plan for uncertainty and prepare for change. Journal of Airport Management, 9, 118-132.

Crawford, G. \& Melewar, T. C. (2003). The importance of impulse purchasing behaviour in the international airport environment. Journal of Consumer Behaviour, 3(1), 85-98.

Czerny, A. I. (2006). Price-Cap regulations of airports: Single-till versus dual-till. Journal of Regulatory Economics, 30(1), 85-97.

De Neufville, R., Odoni, A., Belobaba, P., \& Reynolds, T. (2013). Airport systems: planning, design, and management. New York: McGraw-Hill Professional.

Doganis, R. (1992). The Airport Business. London: Routledge.

Francis, G. Humphreys, I. \& Ison, S. (2004). 'Airports' perspectives on the growth of low-cost airlines and the remodelling of the airport-airline relationship. Tourism Management, 25(4), 507-514.

Freathy, P \& O'Connell, F. (1999). Planning for profit: Commercialization of European airports. Long Range Planning, 32, 587-597.

Freathy, P. \& O'Connell, F. (2000). Market segmentation in the European airport sector. Marketing Intelligence $\mathcal{E}$ Planning, 18(3), 102-111.

Freathy, P. (2004). The commercialisation of European airports: successful strategies in a decade of turbulence? Journal of Air Transport Management, 10, 191-197.

Fuerst, F., Gross, S. \& Klose, U. (2011). The sky is the limit? The determinants and constraints of European airports commercial revenues. Journal of Air Transport Management, 17(5), 278-283.

Graham, A. (2003). Managing Airports: an international perspective, 2nd edition. Oxford: Elsevier, ButterworthHeinemann.

Graham, A. (2008). How important are commercial revenues to today's airports? Journal of Air Transport Management, 1-6.

Graham, A. (2008). Managing Airports 3rd Edition: An International Perspective. Oxford: Butterworth-Heinemann. 
Graham, A. (2009). How important are commercial revenues to today's airports? Journal of Air Transport Management, $15,106-111$.

Graham, A. (2013). Understanding the low-cost carrier and airport relationship: A critical analysis of the salient issues. Tourism Management, 36, 66-76.

Gillen, D. \& Martin, B. (2014). The importance of concession revenues in the privatization of airports. Transportation Research Part E: Logistics and Transportation Review, 68, 164-177.

Herring, AB. (2002). Current Approaches to the Development of Airport Retail: A Sales Performance Analysis and Case Study. Massachusetts: Massachusetts Institute of Technology.

Heyes, G. (2014). The future of airport retail in a carbon constrained world: Setting the agenda for research. Social Business, 4, 45-62.

Kazda, A. \& Caves, R.E. (2007). Airport design and operation (2nd Edition). Oxford: Elsevier.

Klos, D. (2014). Airports as cities- the concept of aerotropolis applied to Helsinki-Vantaa International Airport. Helsinki: Haaga-Helia University of Applied Sciences

Kraal, B. Popovic, V. \& Kirk P. J. (2009). Passengers in the airport: artefacts and activities. Melbourne, Ozchi.

Kramer, L. S. (2010). Airport Revenue Diversification. Washington: Transportation Research Board.

Kramer, L. S., Landau, S., Letwin, J. \& Moroney, M. (2015). Innovative revenue strategies - An airport guide (ACRP Report 121). Washington DC: National Academy of Sciences.

Little, A. D. (2009). Mastering Airport Retail. Unknown: Arthur D Little.

Livingstone, A. K. (2014). Passenger Experience and Their Implications for Airport Retail Environment Design. Queensland: Queensland University of Technology.

London First. (2008). Imagine a world class Heathrow. London: London First.

Moodie, M. (2007). Analysing airport commercial revenues ACI Airport Economics Survey 2006. Canada: Airport Council International.

Moodie, M. (2007). Analysing airport commercial revenues. Airport Council International, ACI Airport Economics Survey 2006, 20-25.

Niemeier, H. M. (2002). Regulation of Airports: The Case of Hamburg Airport - a view from the perspective of regional policy. Journal of Air Transport Management, 8(1), 37-48.

Omar, O. (2001). Airport retailing: Examining airline passengers' impulsive shopping behaviour. Journal of Euromarketing, 11(1), 87-105.

Oum, T. H., Adler, N. \& Yu, C. (2006). Privatization, corporatization, ownership forms and their effects on the performance of the world's major airports. Journal of Air Transport Management, 12(3), 109-121.

Papagiorcopulo, G. (1994). The importance of non-aviation revenues to a small airport inCommercial Airport, $1994 / 95$. London: Stirling.

Rimmer, J. (2011). The Airport Commercial Revenues Study (ACRS) 2010/11. Unknown: The Moodie Report in cooperation with the S-A-P Group.

Rowley, J \& Slack, F. (1999). The retail experience in airport departure lounges: Reaching for timelessness and placelessness. [Research Paper]. International Marketing Review, 16(4/5), 363-376.

Saounatsos, G. (2007). Airport Charges. Airports International, 40(8), 56-63.

Tourism Forecasting Committee. (2011). Forecast 2011 Issue 2. Canberra: Australian Government.

Tymkiw, A. D. (2016). Emotions Involved in Shopping at the Airport. Mississippi: The University of Southern Mississippi.

Van Denver, K. (2007). Determinants of fares and operating revenues at US Airports. Journal of Urban Economics, 62(2), 317-326.

Wells, A. T. \& Young, S. (2004). Airport Planning \& Management. New York: McGraw-Hill Professional.

Zhang, A. \& Zhang, Y. (1997). Concession revenue and optimal airport pricing. Transportation Research Part E: Logistics and Transportation Review, 33(4) 